\title{
Peningkatkan Sikap Ilmiah Siswa Melalui Penerapan Model Discovery Learning
}

\author{
Arti Asmarani ${ }^{1 *}$, Irdam Idrus ${ }^{1}$, Kasrina $^{1}$ \\ ${ }^{1}$ Program Studi Pendidikan Biologi, Fakultas Keguruan dan Ilmu Pendidikan, Universitas Bengkulu \\ Email : asmaraniartie@gmail.com
}

\begin{abstract}
ABSTRAK
Penelitian ini bertujuan untuk mendeskripsikan sikap ilmiah siswa dan penerapan model discovery learning di kelas VIIC SMPN 15 Kota Bengkulu. Jenis penelitian ini adalah penelitian tindakan kelas dengan metode deskriptif, penelitian terdiri dari dua siklus dengan setiap siklusnya terdiri atas tahap perencanaan, pelaksanaan tindakan dan observasi dan refleksi. Subyek penelitian adalah guru dan seluruh siswa kelas VIIc SMPN 15 Kota Bengkulu tahun ajaran 2016/2017 siswa. Variabel penelitian ini adalah model pembelajaran discovery learning dan sikap ilmiah siswa. Teknik pengumpulan data dalam penelitian ini yaitu observasi dan penilaian diri dengan instrumen berupa lembar observasi dan lembar penilaian diri. Hasil analisis data aktivitas guru siklus I diperoleh skor rata-rata yaitu 11,5 (Cukup), dan pada siklus II skor rata-rata aktivitas guru menjadi 15 (Baik). Selanjutnya data sikap ilmiah siswa pada siklus I diperoleh skor rata-rata 16,90 (Cukup) dan pada siklus II sikap ilmiah siswa mengalami peningkatan skor rata-rata yaitu 20,99 (Baik). Dari hasil penelitian dapat disimpulkan bahwa model Pembelajaran Discovery Learning dapat meningkatkan sikap ilmiah siswa kelas VIIc SMPN 15 Kota Bengkulu.
\end{abstract}

Kata Kunci : Model Pembelajaran Discovery Learning, Sikap Ilmiah.

\section{ABSTRACT}

This study aimed to describe of student's scientific attitude and discovery learning model application in the class VIIc SMP Negeri 15 Bengkulu city. This research is a classroom action research with descriptive methods, consisted of two cycles each cycle consisting of planning, implementation, observation and reflection. The subjects were teacher and all students in the class VIIc SMPN 15 Bengkulu City 2016/2017 school year. The variables of this research is a model of discovery Learning, student's scientific attitude. Data collection techniques are observation and self-assesment with the istrument used is observation sheet and self-assesment sheet. The results of data analysis of teacher activity first cycle obtained average score of 11,5 (enough), and on the second cycle of teacher activity score to 15 (Good). The results of data of student's scientific attitude first cycle obtained average score of 16,90 (enough), and on the second cycle student's scientific attitude score to be increased of 20,99 (Good). From result of research can be concluded that discovery Learning can increase student's scientific attitude of class VIIc SMPN 15 Bengkulu city

Keywords: Discovery Learning, student's scientific attitude

\section{PENDAHULUAN}

Kemendikbud menjelaskan bahwa kegiatan pembelajaran yang menekankan pada pembelajaran siswa aktif dalam menemukan konsep sendiri diantaranya adalah model discovery learning. Menurut Anam (2016) pembelajaran model discovery learning yakni proses pembelajaran yang berfokus pada penemuan masalah (sumber belajar) yang berasal dari pengalaman-pengalaman nyata siswa sehingga model discovery learning juga menuntut siswa untuk menemukan konsep atau memahami materi melalui serangkaian data dan informasi yang diperoleh berdasarkan pengamatan atau percobaan pada proses pembelajaran yang dapat mengembangkan sikap ilmiah siswa.

Sikap ilmiah diperlukan dari kegiatan pembelajaran yang diperoleh melalui 
proses seperti pengalaman, pembelajaran, identifikasi permasalahan dan lainnya. Pembelajaran dengan model discovery learning diharapkan dapat mempengaruhi sikap positif atau sikap ilmiah siswa yang diperlukan untuk meningkatkan kemampuan siswa demi tercapainya tujuan pembelajaran. Sikap ilmiah terdiri dari beberapa dimensi yaitu sikap ingin tahu, sikap senantiasa mendahulukan data/fakta, sikap berfikir kritis, sikap penemuan kreativitas, sikap berpikiran terbuka dan kerjasama, sikap ketekunan, sikap peka terhadap lingkungan sekitar (Kusuma, 2013).

Rizar (2014) menyatakan bahwa pembelajaran IPA dicirikan oleh nilai-nilai dan sikap ilmuwan dalam menggunakan proses ilmiah untuk mendapatkan pengetahuan, hal ini sesuai dengan pendekatan saintifik yang digunakan dalam kurikulum 2013. Materi pencemaran lingkungan dengan Kompetensi Dasar (KD) 3.9. Mendeskripsikan pencemaran dan dampaknya bagi makhluk hidup, berdasarkan KD yang akan dicapai dalam materi pencemaran lingkungan diharapkan dapat meningkatkan sikap ilmiah siswa berdasarkan kegiatan pembelajaran untuk mendeskripsikan terjadinya pencemaran lingkungan dan dampaknya bagi mahkluk hidup dengan penerapan model pembelajaran discovery learning.

Berdasarkan hasil diskusi dan observasi peneliti dengan guru biologi di SMPN 15 Kota Bengkulu, ada beberapa masalah yang ditemui dalam proses pembelajaran, yaitu : 1) Kegiatan pembelajaran masih berpusat pada guru sehingga siswa kurang aktif dan sikap ilmiah kurang berkembang; 2) Dalam mendapatkan pengetahuan siswa terpaku pada buku pelajaran bukan pada proses pembelajaran sehingga sikap ilmiah siswa kurang berkembang.
Berdasarkan permasalahan yang diuraikan diatas maka peneliti melaksanakan penelitian berupa pening-katkan sikap ilmiah siswa melalui penerapan model discovery learning pada materi pencemaran lingkungan di kelas VIIC SMPN 15 Kota Bengkulu. Berdasarkan latar belakang masalah yang telah diuraikan diatas, maka rumusan masalah dalam penelitian ini adalah sebagai berikut : apakah penerapan model discovery learning di kelas VIIC SMPN 15 Kota Bengkulu dapat meningkatkan sikap ilmiah siswa siswa pada materi pencemaran lingkungan?. Tujuan penelitian adalah untuk mendeskripsikan sikap ilmiah siswa melalui penerapan model discovery learning pada pembelajaran materi pencemaran lingkungan di kelas VIIC SMPN 15 Kota Bengkulu

\section{METODE}

Jenis penelitian yang digunakan adalah Penelitian Tindakan Kelas dengan metode deskriptif. Subyek penelitian adalah guru dan seluruh siswa kelas VIIc SMPN 15 Kota Bengkulu tahun ajaran 2016/2017 dengan penentuan subyek secara convenience sampling yaitu sampel berdasarkan kemudahan atau ketersediaan di sekolah untuk dilaksanakannya penelitian yang dalam hal ini peneliti sebagai guru dalam penelitian dengan teknik pengumpulan data yaitu observasi yang dilakukan untuk mengamati aktivitas guru dan sikap ilmiah siswa dengan instrumen berupa lembar observasi dengan kategori baik, cukup dan kurang, butir observasi dikembangkan dari langkah-langkah model discovery learning. Selain itu observasi, penilaian diri digunakan untuk menilai sikap ilmiah oleh siswa secara sendiri berdasarkan kegiatan pembelajaran yang telah dilakukan dengan memberi tanda ( $\mathrm{V}$ ) pada tiga kategori yaitu ya, kadang-kadang dan tidak pada lembar penilaian diri. Butir pernyataan sikap 
ilmiah pada lembar observasi dan lembar penilaian diri dikembangkan berdasarkan dimensi dan indikator sikap ilmiah.

Teknik analisis data aktivitas guru dan sikap ilmiah siswa dianalisis secara deskriptif dengan cara mencari rerata dan kategori. Rumus rerata Susetyo (2012) :

Rerata Skor : $\frac{\sum X}{n}$

$\Sigma X \quad=$ jumlah seluruh skor pengamatan

$n \quad=$ jumlah observer/pengamat

Kategori rerata dan skor aspek pembelajaran dikategorikan dalam kategori baik, cukup, dan kurang. Penentuan kategori skor setiap kategori menggunakan rumus menurut Sudijono (2012), yaitu:

Rentang tiap kategori $=$ skor maksimum - skor minimum

jumlah kategori
Keterangan :

skor terbesar $=$ jumlah butir pengamatan $x$ skor maksimum setiap butir

skor terkecil = jumlah butir pengamatan $\mathrm{x}$ skor minimum setiap butir

\section{HASIL DAN PEMBAHASAN}

1. Penerapan model discovery learning dan sikap ilmiah siswa pada siklus I dan siklus II

Berdasarkan penelitian yang telah dilakukan berupa peningkatkan sikap ilmiah siswa menggunakan penerapan model discovery learning pada materi pencemaran lingkungan di kelas VIIC SMPN 15 Kota Bengkulu yang dilaksanakan selama 2 siklus maka diperoleh hasil sebagai berikut:

Tabel 1. Data aktivitas guru dan sikap ilmiah siswa pada siklus I dan siklus II

\begin{tabular}{|c|c|c|c|c|c|c|c|c|c|c|}
\hline \multirow[t]{3}{*}{ Siklus } & \multicolumn{5}{|c|}{ Sikap ilmiah siswa } & \multicolumn{5}{|c|}{ Aktivitas guru } \\
\hline & \multirow[t]{2}{*}{ Observasi } & \multirow{2}{*}{$\begin{array}{l}\text { Penilai } \\
\text { an diri }\end{array}$} & \multirow[t]{2}{*}{ Total } & \multirow{2}{*}{$\begin{array}{c}\text { Rata- } \\
\text { rata }\end{array}$} & \multirow[t]{2}{*}{ Kategori } & \multicolumn{2}{|c|}{ Observer } & \multirow[t]{2}{*}{ Total } & \multirow{2}{*}{$\begin{array}{l}\text { Rata- } \\
\text { rata }\end{array}$} & \multirow[t]{2}{*}{ Kategori } \\
\hline & & & & & & 1 & 2 & & & \\
\hline 1 & 14,23 & 19,58 & 33,81 & 16,90 & Cukup & 11 & 12 & 23 & 11,5 & Cukup \\
\hline 2 & 20,08 & 21,91 & 41,99 & 20,99 & Baik & 14 & 16 & 30 & 15 & Baik \\
\hline
\end{tabular}

Berdasarkan Tabel 1. diatas aktivitas guru berupa penerapan model discovery learning secara keseluruhan terjadi peningkatan kegiatan pembelajaran dari siklus I dengan kategori cukup meningkat menjadi kategori baik di siklus II. Peningkatan kegiatan pembelajaran pada siklus II ini seiring dengan dilakukannya perbaikan setiap tahapan model discovery learning dalam pembelajaran pada siklus I yang dinilai kurang maksimal. Hal ini sesuai dengan pendapat McNiff (1992) dalam Winarni (2011), dimana Penelitian Tindakan Kelas (classroom action research) adalah bentuk penelitian reflektif yang dilakukan oleh guru yang hasilnya dapat dimanfaatkan sebagai alat untuk pengembangan keahian mengajar, yaitu melalui penelitian tindakan, guru dapat memperbaiki praktek-praktek pembelajaran menjadi lebih efektif sehingga kualitas pembelajaran menjadi lebih baik dari kegiatan pembelajaran sebelumnya.

Peningkatan aktivitas guru dalam penerapan model discovery learning dalam proses pembeljaran dapat meningkatkan sikap ilmiah sesuai dengan pendapat menurut Anam (2016), dimana pembelajaran model discovery learning 
yakni proses pembelajaran yang berfokus pada penemuan masalah (sumber belajar) yang berasal dari pengalaman nyata siswa. Sehingga dalam proses pembelajaran siswa dituntut untuk dapat menyelesaikan masalah (materi ajar) dalam hal ini pembelajaran model discovery learning juga menuntut siswa untuk menemukan konsep atau memahami materi melalui serangkaian data dan informasi yang diperoleh berdasarkan pengamatan atau percobaan pada proses pembelajaran sehingga siswa dapat belajar aktif yang mengembangkan sikap ilmiah siswa.

\section{Dimensi sikap ilmiah pada siklus I dan siklus II}

Ada 4 dimensi sikap ilmiah yang dipilih untuk diamati dalam penelitian yaitu sikap ingin tahu, sikap berpikir kritis, sikap peka terhadap lingkungan sekitar dan sikap bekerja sama yang dapat diamati pada Tabel berikut ini :

Tabel 2. Data dimensi sikap ilmiah siswa pada siklus I dan siklus II

\begin{tabular}{ccccccccc}
\hline $\begin{array}{c}\text { Dimensi } \\
\text { sikap } \\
\text { ilmiah }\end{array}$ & \multicolumn{9}{c}{ Siklus I } & Observasi & $\begin{array}{c}\text { Penilaian } \\
\text { diri }\end{array}$ & $\begin{array}{c}\text { Rata- } \\
\text { rata }\end{array}$ & Kategori & Observasi & $\begin{array}{c}\text { Penilaian } \\
\text { diri }\end{array}$ & $\begin{array}{c}\text { Rata- } \\
\text { rata }\end{array}$ & Kategori \\
\hline Ingin tahu & 1,78 & 2,34 & 2,06 & Cukup & 2,51 & 2,69 & 2,6 & Baik \\
\hline $\begin{array}{c}\text { Berfikir } \\
\text { kritis }\end{array}$ & 1,87 & 2,38 & 2,12 & Cukup & 2,41 & 2,41 & 2,41 & Baik \\
$\begin{array}{c}\text { Peka } \\
\text { terhadap }\end{array}$ & 1,81 & 2,51 & 2,16 & Cukup & 2,52 & 2,75 & 2,63 & Baik \\
$\begin{array}{c}\text { lingkunga } \\
\text { n sekitar } \\
\text { Bekerja } \\
\text { sama }\end{array}$ & 1,68 & 2,55 & 2,11 & Cukup & 2,52 & 2,88 & 2,7 & Baik \\
\hline
\end{tabular}

Berdasarkan Tabel 2. diatas, pada siklus I keempat dimensi sikap ilmiah dalam kategori cukup dari penilaian observer dalam lembar observasi maupun lembar penilaian diri siswa secara sendiri sedangkan pada siklus II keempat dimensi sikap ilmiah siswa dari lembar observasi maupun lembar penilaian diri siswa meningkat menjadi kategori baik. Dimensi sikap ingin tahu pada siklus I memiliki rata-rata skor paling kecil dari dimensi sikap ilmiah lainnya yaitu 2,06, indikator sikap antusias siswa dalam belajar dan sikap menanyakan setiap perubahan/hal baru masih dinilai cukup, hal ini karena hanya beberapa siswa saja yang bertanya akan tetapi pertanyaan yang diajukan kurang sesuai dengan materi yang dipelajari.

Pada siklus II dimensi sikap ingin tahu dalam kategori baik dengan rata-rata skor 2,6 dimana indikator sikap antusias siswa dalam belajar dan sikap menanyakan setiap perubahan/hal baru ini meningkat karena peneliti membimbing siswa dalam memusatkan perhatian pada gambar/video yang disajikan dan membimbing siswa dalam menanggapinya. Peneliti juga membimbing siswa dalam kegiatan percobaan yang dilakukan serta membimbing siswa menjawab pertanyaan pada LKS berdasarkan percobaan yang dilakukan sehingga muncul sikap ingin tahu siswa dimana pada siklus II ini siswa sudah banyak yang bertanya mengenai percobaan dan materi yang diajarkan. 
Dimensi sikap berpikir kritis siswa juga meningkat pada siklus II dengan ratarata skor 2,41 yaitu kategori baik yang merupakan perbaikan dari siklus I dengan rata-rata skor untuk dimensi sikap berpikir kritis siswa 2,12 dengan kategori cukup. Indikator dimensi sikap berpikir kritis siswa berupa sikap kurang percaya atau meragukan pendapat orang lain. Pada siklus I banyak siswa yang kurang peduli terhadap pendapat atau temuan siswa lainnya pada pengamatan, sehingga siswa hanya ikut-ikutan saja terhadap pendapat atau temuan temannya. Sedangkan pada siklus II peneliti membimbing siswa untuk bersikap skeptis atau tidak percaya begitu saja mengenai pendapat atau temuan temannya dengan cara guru meminta siswa untuk menanggapi pertanyaan ataupun tanggapan dengan mendiskusikannya bersama seluruh siswa dalam kelas serta meminta siswa memberikan alasan mengenai pendapat/tanggapannya.

Dimensi sikap peka terhadap lingkungan sekitar, dengan indikator meliputi sikap menjaga kebersihan kelas yang disesuaikan dengan materi yang diajarkan yaitu mengenai pencemaran lingkungan serta dampak pencemaran lingkungan bagi makhluk hidup. Berdasarkan kegiatan pembelajaran harapannya siswa dapat menjaga kebersihan lingkungan kelasnya selama proses pembelajaran hingga pembelajaran berakhir. Pada siklus I dimensi sikap peka terhadap lingkungan sekitar ini memiliki kategori cukup dengan rata-rata skor 2,16 , hal ini karena dalam proses pembelajaran siswa tidak menjaga kebersihan kelasnya, dimana masih banyak sampah berupa kertas ataupun bungkus makanan yang ada dibawah meja dan kursi siswa selain itu, setelah percobaan selesai siswa tidak membereskan alat dan bahan yang telah digunakan. Pada siklus II dimensi sikap peka terhadap lingkungan sekitar meningkat menjadi kategori baik dengan rata-rata skor 2, 63. Hal ini karena pada siklus II ini guru memberikan bimbingan kepada siswa untuk senantiasa menjaga kebersihan lingkungan kelas dan membereskan alat dan bahan yang digunakan setelah percobaan selesai dengan cara meminta setiap kelompok untuk berbagi tugas menjaga kebersihan sekitar kelompoknya dan siswa yang bertugas untuk mengambil/membereskan alat dan bahan yang telah digunakan pada percobaan.

Dimensi sikap yang terakhir adalah dimensi sikap bekerja sama dengan indikator sikap berpartisipasi aktif dalam kelompoknya dan sikap menerima saran teman dan tidak merasa paling benar dalam kelompoknya. Pada siklus I siswa kurang bekerja sama dengan kelompoknya dimana be-berapa siswa merasa paling pintar sehing-ga dalam mengerjakan LKS siswa tidak berdiskusi dengan teman kelompoknya sedangkan siswa yang lainnya hanya bermain main saja dan tidak peduli terhadap pengerjaan LKS. Berdasarkan hal tersebut rata-rata skor untuk dimensi sikap bekerja sama siswa pada siklus I yaitu 2,11 dengan kategori cukup. Di siklus II peneliti memperbaiki kegiatan pem-belajaran berdasarkan kekurangan pada siklus I, agar terciptanya kelompok siswa yang dapat bekerja sama guru meminta setiap kelompok untuk membagi tugas setiap anggota kelompoknya seperti tugas untuk mengamati percobaan, tugas men-cari literatur di buku paket, tugas menulis serta mendiskusikan secara bersamasama jawaban dari pertanyaan pada LKS. Berda-sarkan perbaikan kegiatan pembelajaran tersebut dimensi sikap ilmiah siswa pada siklus II mengalami peningkatan rata-rata skor menjadi 2,7 dengan kategori baik. Berikut ini grafik peningkatan sikap ilmiah siswa melalui penerapan model discovery learning yang dilaksanakan dalam 2 siklus : 


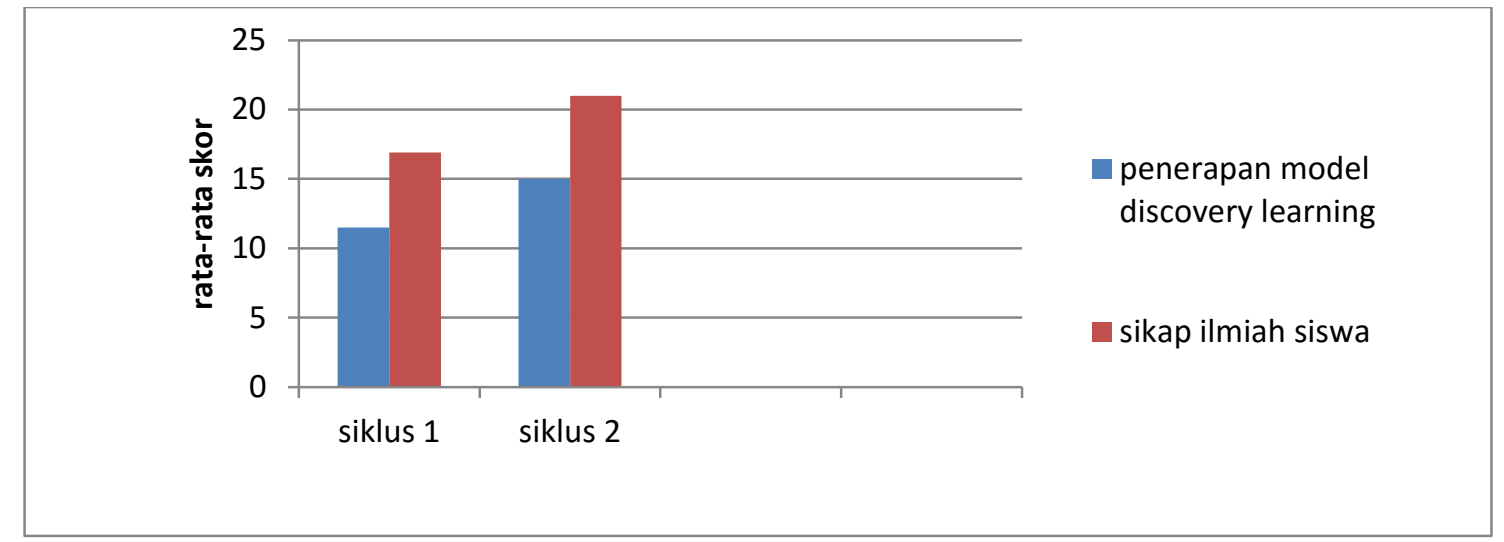

Gambar 1. Peningkatan penerapan model discovery learning dan sikap ilmiah siswa pada siklus I dan II

\section{PENUTUP}

\section{Simpulan}

Sikap ilmiah siswa kelas VIIc SMPN 15 Kota Bengkulu meningkat dari kategori cukup pada siklus I menjadi ketegori baik pada siklus II untuk setiap dimensi sikap yaitu sikap ingin tahu, sikap berpikir kritis, sikap peka terhadap lingkungan sekitar dan sikap bekerja sama sebagai respon dari kegiatan pembelajaran menggunakan model discovery learning.

\section{Saran}

Dalam tahapan penerapan model discovery learning hendaknya guru lebih memperhatikan dan membimbing siswa dalam setiap tahapannya. 


\section{Daftar Pustaka}

Anam, Khoirul. 2016. Pembelajaran Berbasis Inkuiri Metode Dan

Kusuma, Merta Dhewa. 2013. Pengaruh Sikap Ilmiah Siswa Terhadap Hasil Belajar Fisika Dan Kemandirian Belajar Siswa SMA Melalui Strategi Scaffolding- Kooperatif. Dalam Jurnal Pembelajaran Fisika Universitas Lampung.

Rosita, Ita. 2014. Meningkatkan Kerja Sama Siswa Melalui Pembelajaran Kooperatif Tipe Think Pair Share. Dalam https:// journal.Ippmunindra.ac.id.

Sudijono, Anas. 2012. Pengantar Statistik Pendidikan. Jakarta : Rajawali Pers.
Aplikasi. Yogyakarta :Pustaka Pelajar.

Rizar, Abidin. 2014. Implementasi Penilaian Hasil Belajar Kurikulum 2013 Pada Program Keahlian Teknik Audio Video Di Smk 2 Surakarta. Dalam Jurnal Hasil Penelitian.

Susetyo, Budi. 2012. Statistika Untuk Analisis Data Penelitian. Bandung : PT Refika Aditama.

Winarni, Endang Widi. 2011. Penelitian Pendidikan. Bengkulu : Unit Penerbitan FKIP UNIB 